\title{
PEMBENTUKAN FUNGSI KETAHANAN HIDUP DAN FUNGSI HAZARD PADA DATA KETAHANAN HIDUP PASIEN PENDERITA DEMAM BERDARAH DENGUE
}

\author{
MUHAMMAD HAFANDRY, DODI DEVIANTO, HAZMIRA YOZZA \\ Program Studi S1 Matematika, \\ Fakultas Matematika dan Ilmu Pengetahuan Alam, Universitas Andalas, \\ Kampus UNAND Limau Manis Padang, Indonesia. \\ email : muhammadhafandry224@gmail.com,ddevianto@sci.unand.ac.id, \\ hazmirayozza@sci.unand.ac.id
}

\author{
Diterima 17 Februari 2020 Direvisi 7 Maret 2020 Dipublikasikan 29 April 2020
}

\begin{abstract}
Abstrak. Demam Berdarah Dengue (DBD) adalah penyakit yang disebabkan oleh virus Dengue yang ditularkan melalui gigitan nyamuk dari genus Aedes aegypti. Analisis ketahanan hidup merupakan teknik statistik yang digunakan untuk menganalisa data ketahanan hidup berupa waktu dari suatu pengamatan sampai terjadinya suatu kejadian. Kejadian yang dimaksud merupakan peristiwa khusus yang terjadi pada suatu individu, misalnya berupa kematian. Pada data ketahanan hidup adanya kemungkinan beberapa individu tidak bisa diobservasi secara lengkap yang disebut dengan data tersensor. Pada data disensor tipe III, percobaan dilakukan untuk individu yang masuk pada waktu yang berlainan dan percobaan dihentikan sampai terjadinya suatu kejadian. Distribusi Weibull dapat digunakan untuk menggambarkan prilaku peluang dari ketahanan hidup. Pada fungsi hazard untuk pasien penderita DBD di RSUP Dr. M. Djamil Padang Tahun 2018 menunjukkan bahwa semakin meningkat waktu lama pasien dirawat maka kelajuan pasien tersebut mengalami kesembuhan semakin meningkat. Pada fungsi ketahanan hidup untuk pasien penderita DBD di RSUP Dr. M. Djamil Padang Tahun 2018 menunjukkan bahwa semakin meningkat waktu lama pasien dirawat maka peluang pasien masih berada dalam perawatan akan semakin kecil.
\end{abstract}

Kata Kunci: Analisis Ketahanan Hidup, Demam Berdarah Dengue, Metode Bayes

\section{Pendahuluan}

Penyakit Demam Berdarah Dengue (DBD) adalah penyakit yang disebabkan oleh virus Dengue yang tergolong Arthropod-Borne Virus, genus Flavivirus, dan famili Flaviviridae. DBD ditularkan melalui gigitan nyamuk dari genus Aedes, terutama Aedes aegypti atau Aedes albopictus [5].

Analisis ketahanan hidup merupakan teknik statistik yang digunakan untuk menganalisa data ketahanan hidup berupa waktu dari suatu pengamatan sampai terjadinya suatu kejadian. Dalam analisis ketahanan hidup terdapat tiga je-

* penulis korespondensi 
nis penyensoran yaitu data disensor tipe I, tipe II, dan tipe III. Pada data disensor tipe I, percobaan akan dihentikan setelah mencapai waktu $T$ yang telah ditentukan. Pada tipe II, dimana pengamatan dihentikan jika r dari n individu mengalami kegagalan. Pada tipe III, percobaan dilakukan untuk individu yang masuk pada waktu yang berlainan dan percobaan dihentikan sampai terjadinya suatu kejadian [3].

Metode Bayes adalah metode pendugaan yang menggabungkan distribusi prior dengan distribusi contoh. Distribusi prior adalah distribusi awal yang memberi informasi tentang parameter. Distribusi contoh yang digabung dengan distribusi prior akan menghasilkan suatu distribusi baru yaitu distribusi posterior. Nilai harapan atau rata-rata distribusi posterior digunakan sebagai nilai dugaan titik bagi parameter [9].

Fungsi yang menggambarkan prilaku ketahanan hidup suatu individu adalah fungsi ketahanan hidup dan fungsi hazard. Fungsi ketahanan hidup adalah fungsi yang menyatakan peluang suatu individu dapat bertahan hidup selama waktu $t$, sedangkan fungsi hazard adalah fungsi kegagalan dari waktu tahan hidup di dalam interval waktu yang sangat kecil.

Pada penelitian ini akan dibahas estimasi parameter $\lambda$ dari data ketahanan hidup, fungsi ketahanan hidup dan fungsi hazard pada data disensor tipe III yang berdistribusi Weibull dengan metode Bayes.

\section{Landasan Teori}

\subsection{Demam Berdarah Dengue}

Penyakit DBD ditemukan pertama kali oleh David Baylon pada tahun 1779. Penyakit ini disebabkan oleh virus Dengue dari genus Flavivirus, famili Flaviviridae. DBD ditularkan ke manusia melalui gigitan nyamuk Aedes yang terinfeksi virus Dengue [10].

Gejala dan tanda utama untuk penderita penyakit DBD adalah demam tinggi yang mendadak, tanda-tanda pendarahan, pembesaran hati, hasil diagnosis, gejala klinis seperti muntah, mual, nyeri kepala, batuk, sesak nafas, dan munculnya bintikbintik merah pada kulit [6].

\subsection{Analisis Ketahanan Hidup}

Analisis ketahanan hidup merupakan teknik statistik yang digunakan untuk menganalisa data ketahanan hidup berupa waktu dari suatu pengamatan sampai terjadinya suatu kejadian. Pada data ketahanan hidup adanya kemungkinan beberapa individu tidak bisa diobservasi secara lengkap yang disebut dengan data tersensor. Data tersensor ditemukan jika [8] :

(1) Objek yang diamati tidak mengalami kejadian apapun.

(2) Objek yang diamati menghilang dalam pengamatan.

(3) Objek yang diamati terpaksa diberhentikan dari pengamatan namun bukan disebabkan oleh kejadian yang diamati, catatan kejadian tidak selalu harus meninggal.

Dalam analisis ketahanan hidup terdapat tiga jenis penyensoran, yaitu [3] : 
(1) Sensor Tipe I.

(2) Sensor Tipe II.

(3) Sensor Tipe III.

Dalam analisis ketahanan hidup terdapat fungsi-fungsi yang digunakan untuk menggambarkan prilaku dari data ketahanan hidup, yaitu :

(1) Fungsi Ketahanan Hidup.

Fungsi ketahanan hidup $S(t)$ adalah fungsi yang menyatakan peluang suatu individu dapat bertahan hidup sampai dengan waktu $t$ dengan $t \geq 0$. Fungsi ketahanan hidup dinyatakan sebagai berikut:

$$
S(t)=1-F(t), t \geq 0 \text {. }
$$

(2) Fungsi Hazard.

Fungsi hazard didefinisikan sebagai kelajuan suatu individu untuk mengalami kegagalan pada interval waktu $t$ sampai $(t+\Delta t)$ apabila diketahui individu tersebut belum mengalami kegagalan sampai dengan waktu $t$. Secara matematis dapat dituliskan sebagai berikut [4]:

$$
h(t)=\frac{f(t)}{S(t)} .
$$

\subsection{Distribusi Weibull}

Definisi 2.1. [7] Suatu peubah acak kontinu T berdistribusi Weibull, dengan $\lambda$ yang menyatakan parameter skala dan parameter $\sigma^{2}$ yang menyatakan parameter bentuk dan ditulis $T \sim W E I\left(\lambda, \sigma^{2}\right)$ maka fungsi kepekatan peluangnya adalah

$$
f(t)=\sigma^{2} \lambda t^{\sigma^{2}-1} \exp \left(-\lambda t^{\sigma^{2}}\right), t>0,
$$

dengan $\sigma^{2}>0, \lambda>0$.

\subsection{Data Tersensor Tipe III}

Fungsi kepekatan peluang untuk data tersensor tipe III berdistribusi Weibull adalah

$$
f\left(t_{i}, \delta_{i}\right)=\left(\lambda \sigma^{2} t_{i}^{\sigma^{2}-1}\right)^{\delta_{i}} \exp \left(-\lambda t_{i}^{\sigma^{2}}\right),
$$

dengan $\delta_{i}=0$ jika observasi ke $i$ tersensor dan $\delta_{i}=1$ jika observasi ke $i$ tidak tersensor.

\subsection{Metode Bayes}

Metode Bayes adalah metode pendugaan yang menggabungkan fungsi likelihood dengan distribusi prior dari parameter yang akan diduga sehingga didapatkan distribusi posterior yang akan menjadi dasar dari pendugaan parameter. 
180 Muhammad Hafandry dkk

\subsection{Fungsi Likelihood}

Definisi 2.2. [1] Fungsi likelihood adalah fungsi dari parameter $\theta$ dinotasikan oleh $L(\theta)$. Jika $X_{1}, X_{2}, \ldots, X_{n}$ menyatakan peubah acak dari distribusi $f(x ; \theta)$, maka fungsi likelihood dituliskan:

$$
L(\theta)=\prod_{i=1}^{n} f\left(x_{i} ; \theta\right) .
$$

\subsection{Distribusi Prior}

Berkaitan dengan informasi terdahulu terkait dengan penentuan sebaran masingmasing parameter pada pola distribusi prior, terdapat 2 tipe distribusi prior, yaitu:

(1) Distribusi prior informatif.

(2) Distribusi prior non-informatif. Salah satu pendekatan dari non-informatif prior adalah metode Jeffrey.

\subsection{Distribusi Posterior}

Distribusi posterior merupakan fungsi kepekatan peluang bersyarat $\theta$ jika $\mathbf{x}$ diketahui sebagaimana dinyatakan

$$
f(\theta \mid \mathbf{x})=\frac{f(\mathbf{x}, \theta)}{f(\mathbf{x})}
$$

\subsection{Uji Kolmogorov-Smirnov}

Hipotesis yang diuji pada uji Kolmogorov-Smirnov ini adalah $H_{0}$ : Data mengikuti distribusi tertentu.

$H_{1}$ : Data tidak mengikuti distribusi tertentu.

Statistik uji yang digunakan adalah

$$
D=\sup |F(x)-S(x)| \text {. }
$$

dengan :

$F(x)=$ Fungsi sebaran kumulatif populasi.

$S(x)=$ Fungsi sebaran kumulatif sampel.

Daerah penolakan $H_{0}$ adalah jika nilai $D_{\text {hitung }}$ lebih besar dari nilai $D_{\text {tabel }}$ yang berarti bahwa data tidak mengikuti distribusi tertentu. Jika $\alpha$ yang digunakan adalah 0.05 dengan jumlah sampel sebanyak $n$, maka $D_{\text {tabel }}$ adalah

$$
D_{\text {tabel }}=\frac{1,36}{\sqrt{n}} .
$$

\section{Pembahasan}

Pada bab ini akan diuraikan bagaimana menduga parameter $\lambda$ berdistribusi Weibull menggunakan metode Bayes dan pembentukan fungsi ketahanan hidup dan fungsi hazard. Pada skripsi ini pendugaan dengan metode Bayes menggunakan prior noninformatif yaitu prior Jeffrey. 


\subsection{Estimasi Parameter $\lambda$ dari Data Disensor Tipe III Berdistribusi Weibull}

Fungsi likelihood untuk data disensor tipe II berdistribusi Weibull dapat dinyatakan sebagai berikut

$$
L(\lambda)=\left(\sigma^{2} \lambda\right)^{\sum_{i=1}^{n} \delta_{i}}\left(\prod_{i=1}^{n}\left(t_{i}^{\sigma^{2}-1}\right)^{\delta_{i}}\right)\left(\exp \left(-\lambda \sum_{i=1}^{n} t_{i}^{\sigma^{2}}\right)\right) .
$$

Distribusi prior untuk $\lambda$ adalah:

$$
\begin{aligned}
g(\lambda) & \propto \sqrt{I(\lambda)}, \\
& =\frac{1}{\lambda}\left(\sum_{i=1}^{n} \delta_{i}\right)^{\frac{1}{2}} .
\end{aligned}
$$

Distribusi posterior dari $\lambda$ adalah

$$
f(\lambda \mid t)=\frac{\left(\sum_{i=1}^{n} t_{i}^{\sigma^{2}}\right)^{\sum_{i=1}^{n} \delta_{i}}}{\Gamma\left(\sum_{i=1}^{n} \delta_{i}\right)} \lambda^{\sum_{i=1}^{n} \delta_{i}-1} \exp \left(-\lambda \sum_{i=1}^{n} t_{i}^{\sigma^{2}}\right) .
$$

Mean posterior dengan penduga bayes untuk $\lambda_{\text {Bayes }}$ adalah $\widehat{\lambda}_{\text {Bayes }}=\frac{\sum_{i=1}^{n} \delta_{i}}{A}$.

\subsection{Pembentukan Fungsi Ketahanan Hidup dan Fungsi Hazard pada Pasien Penderita Demam Berdarah Dengue}

Pada tahap awal, akan diuji terlebih dahulu apakah lamanya waktu tahan hidup pasien DBD berdistribusi Weibull dengan pengujian dilakukan dengan Kolmogorov - Smirnov, dengan hipotesis sebagai berikut :

$H_{0}$ : Data waktu tahan hidup mengikuti distribusi Weibull.

$H_{1}$ : Data waktu tahan hidup tidak mengikuti distribusi Weibull.

Pada hasil pengujian data dengan software Easyfit dapat diketahui bahwa data lama rawat pasien penderita DBD di RSUP Dr. M. Djamil Padang Tahun 2018 berdistribusi Weibull.

Setelah diketahui bahwa data berdistribusi Weibull maka langkah selanjutnya adalah mencari penduga titik dari parameter distribusi Weibull pada data disensor tipe III dengan metode Bayes.

Nilai mean posterior $\lambda_{\text {Bayes }}$ adalah sebagai berikut:

$$
\widehat{\lambda}_{\text {Bayes }}=1.3 \times 10^{-12} \text {. }
$$

Fungsi kegagalannya (hazard) sebagai berikut:

$$
\begin{aligned}
h(t) & =\sigma^{2} \lambda t^{\sigma^{2}-1} \\
& =27.4 \times 10^{-23} t^{3.36} .
\end{aligned}
$$

Gambar 1. menunjukkan bahwa fungsi $h(t)$ tersebut mengukur kelajuan pasien mengalami kesembuhan selama $t$. Semakin meningkat waktu $t$ suatu individu maka 


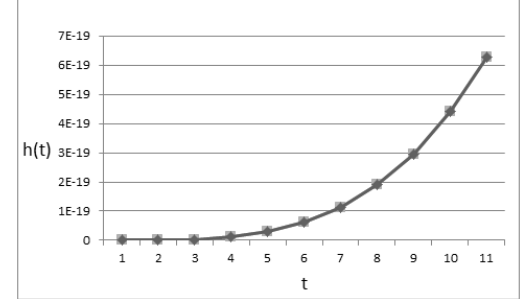

Gambar 1. Fungsi hazard dengan berbagai nilai t

kelajuan individu mengalami kesembuhan semakin meningkat. Fungsi ketahanan hidup sebagai berikut:

$$
\begin{aligned}
S(t) & =\exp \left(-\lambda t^{\sigma^{2}}\right) \\
& =\exp \left(-\left(6.3 \times 10^{-23}\right) t^{4.36}\right) .
\end{aligned}
$$

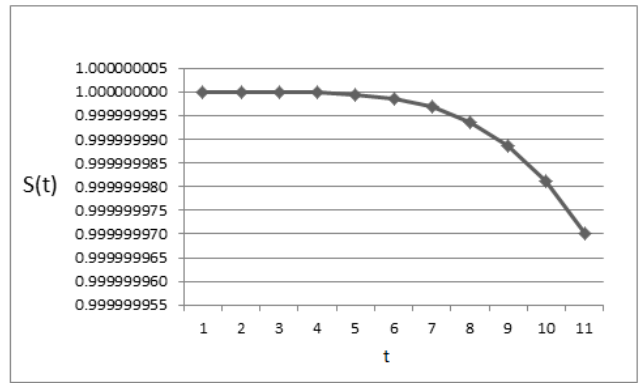

Gambar 2. Fungsi ketahanan hidup dengan berbagai nilai t

Gambar 2. menunjukkan bahwa peluang pasien tersebut mampu bertahan hidup selama waktu $t$ adalah sebesar $S(t)$. Untuk nilai $t$ semakin meningkat maka peluang pasien masih berada dalam perawatan semakin kecil.

\section{Kesimpulan}

Pada fungsi ketahanan hidup untuk pasien penderita DBD di RSUP Dr. M. Djamil Padang Tahun 2018 menunjukkan bahwa semakin meningkat waktu $t$ suatu pasien maka peluang pasien masih berada dalam perawatan semakin kecil dan pada fungsi hazard pada data ketahanan hidup pasien penderita DBD di RSUP Dr. M. Djamil Padang Tahun 2018 menunjukkan bahwa semakin meningkat waktu $t$ suatu pasien maka kelajuan pasien mengalami kesembuhan semakin meningkat. 


\section{Daftar Pustaka}

[1] Bain, L.J. and M.Engelhardt. 1992. Introduction to Probability and Mathematical Statistic. Second Edition. Duxbury Press, California.

[2] Berger, J.O. 1993. Statistical Decision Theory And Bayesian Analysis. Second Edition. Sringer-Verlug, New York.

[3] Collect, D. 1994. Modelling Survival Data in Medical Research. Edisi ke-2. Chapman and Hall

[4] Harlan, J. 2017. Analisis Survival. Gunadarma:Depok.

[5] Kementrian Kesehatan RI. 2015. Profil Kesehatan Indonesia tahun $201 \%$. Jakarta: Kementerian Kesehatan RI.

[6] Kementrian Kesehatan RI. 2017. Pengendalian Demam Berdarah Dengue di Indonesia, Jakarta : Kementerian Kesehatan RI.

[7] Lawless, J. K. 2000. Statistical Models and Methods for Lifetime Data. New York : John Wiley and Sons,Inc.

[8] Le, C. T. 1997.Applied Survival Analysis. New York: John Wiley and Sons, Inc.

[9] Walpole dan R.H. Myers. 1995. Ilmu Peluang dan Statistika untuk Insinyur dan Ilmuwan. Edisi Keempat. ITB, Bandung.

[10] Zuhrat, Lily dkk. 2015. Pemodelan Jumlah Kasus DBD yang Meninggal di Kota Padang dengan Menggunakan Regresi Poisson. Jurnal Matematika UNAND $4: 57-64$. 